\title{
ZINC-BINDING OF THE CYSTEINE-RICH DOMAIN ENCODED IN THE OPEN READING FRAME 1B OF THE RNA POLYMERASE GENE OF CORONAVIRUS
}

\author{
Dongwan Yoo, ${ }^{1}$ Michael D. Parker, ${ }^{2}$ Graham J. Cox,${ }^{1}$ and \\ Lorne A. Babiuk ${ }^{1}$ \\ ${ }^{1}$ Veterinary Infectious Disease Organization \\ University of Saskatchewan \\ Saskatoon, Saskatchewan S7N 0W0 Canada \\ ${ }^{2}$ Virology Annex \\ USAMRIID \\ Frederick, Maryland 21701-5000
}

\begin{abstract}
We cloned and sequenced the second open reading frame of the RNA polymerase gene, ORF1b, of bovine coronavirus. In the region representing nucleotide positions 49195677 upstream from the initiation codon of the $32 \mathrm{~K}$ non-structural protein gene, we identified two putative functional domains. One of these domains contained four leucine residues repeated exactly in every seventh position, and the other domain represented a cluster of cysteine and histidine residues. The DNA sequence representing these domains was cloned and expressed in Escherichia coli as fusion proteins with glutathione S-transferase from Schistosoma japonicum. A high level expression of the cysteine-rich domain was achieved as a fusion protein when the bacterial culture was induced with IPTG. In a solid phase zinc binding assay using the recombinant fusion protein, we found that the protein containing the cysteine-rich domain was able to bind to radioactive zinc in vitro, demonstrating that the polypeptide encoded by the ORF1b of coronavirus is a zinc-binding protein.
\end{abstract}

\section{INTRODUCTION}

The $5^{\prime}$ most gene of coronavirus genome represents gene 1 encoding the putative RNA-dependent RNA polymerase. Gene 1 has been cloned and sequenced in several coronaviruses including infectious bronchitis virus ${ }^{2}$, mouse hepatitis virus ${ }^{3,8,10}$, and human coronavirus strain $229 \mathrm{E}^{6}$. Two large, slightly overlapping open reading frames, termed 
ORF1a and ORF1b, are found in coronavirus gene 1, and it has been suggested that gene 1 is able to synthesize both the ORF1a protein and the ORF1a/ORF1b fusion protein by way of ribosomal frameshifting of the two overlapping open reading frames ${ }^{4}$. Several putative functional domains have been suggested in the ORF1b, which include RNA polymerase, helicase-like, and cysteine-rich domains. None of these domains in coronavirus have been functionally characterized yet. We have been particularly interested in the significance of the cysteine-rich domain of the bovine coronavirus ORF1b. Modeling of the cysteine-rich domain suggests that cysteine/histidine ligands are configured as to tetrahedrally coordinate zinc ions, forming three potential finger-like structures ${ }^{8}$. In this study, we characterized this domain by expressing the DNA fragment as a fusion protein in E. coli, and demonstrated the cysteine-rich domain is able to bind to zinc.

\section{MATERIALS AND METHODS}

Protein expression in E. coli. E. coli transformants were grown in $2 \mathrm{ml}$ of $2 \mathrm{X}$ YT $(1.6 \%$ tryptone, $1 \%$ yeast extract, $0.5 \% \mathrm{NaCl})$ containing $2 \%$ glucose and $100 \mu \mathrm{g} / \mathrm{ml}$ ampicillin to an optical density of 0.5 at $600 \mathrm{~nm}$. Fusion protein was expressed by adding isopropyl- $\beta$-D-thiogalactosidase at final concentration of $2 \mathrm{mM}$, and the culture was further incubated for an additional 2 hours. Cells were pelleted in a microcentrifuge and resuspended in water. The cell suspension was mixed with an equal volume of $2 \mathrm{X}$ Laemmli's sample buffer, boiled for $5 \mathrm{~min}$, and analysed by $12 \%$ SDS polyacrylamide gel electrophoresis. Proteins were visualized by Coommassie blue staining.

Solid phase zinc blot assay. The proteins were resolved by $12 \%$ SDS-polyacrylamide gel electrophoresis and transferred to polyvinylidone difluoride membrane (PVDF; Du Pont). The PVDF membrane was wetted in methanol for 2 min, soaked in water for $5 \mathrm{~min}$, and equilibrated in transfer buffer $(25 \mathrm{mM}$ Tris base, $192 \mathrm{mM}$ glycine, $20 \%$ methanol, $\mathrm{pH}$ 8.3 ) for 10 min before use. For the zinc binding assay ${ }^{12}$, the membrane was briefly washed twice with renaturation buffer $(100 \mathrm{mM}$ Tris- $\mathrm{HCl}, \mathrm{pH} 6.8,50 \mathrm{mM} \mathrm{NaCl}, 10 \mathrm{mM}$ DTT) and incubated in renaturation buffer for $1 \mathrm{hr}$ with three exchanges of buffer at room temperature. The membrane was then incubated in labeling buffer $(100 \mathrm{mM}$ Tris- $\mathrm{HCl}, \mathrm{pH} 6.8,50 \mathrm{mM}$ $\mathrm{NaCl}$ ) containing $1 \mu \mathrm{Ci} / \mathrm{ml}$ of $\mathrm{Zn}^{65}$ (New England Nuclear) for $1 \mathrm{hr}$ with gentle shaking. At the end of incubation, the membrane was rinsed twice with washing buffer $(100 \mathrm{mM}$ Tris- $\mathrm{HCl}, \mathrm{pH} 6.8,50 \mathrm{mM} \mathrm{NaCl}, 1 \mathrm{mM}$ DTT) and washed extensively in washing buffer with three exchanges of buffer for $1 \mathrm{hr}$ at room temperature. The membrane was wrapped with Saran-Wrap and exposed to X-ray film (Reflection ${ }^{\mathrm{TM}}$, Du Pont) at -70 C.

Northwestern blot assay. The protein-RNA binding assay was performed by the procedure described previously with a minor modification ${ }^{1}$. Proteins were resolved by $12 \%$ SDS-PAGE and electro-transferred to PVDF membrane. The membranes were washed for $1 \mathrm{hr}$ at room temperature in probe buffer containing $10 \mathrm{mM}$ Tris- $\mathrm{HCl}, \mathrm{pH} 7.5,50 \mathrm{mM} \mathrm{NaCl}$, $1 \mathrm{mM} \mathrm{Na} 2$ EDTA, $0.02 \%$ bovine serum albumin fraction $\mathrm{V}, 0.02 \%$ polyvinyl pyrrolidone, $0.02 \%$ Ficoll type 400 (Pharmacia), and $250 \mu \mathrm{g} / \mathrm{ml}$ of total E.coli RNA. Approximately $2 \mathrm{X}$ $10^{6}$ counts per minute of ${ }^{32} \mathrm{P}$-labeled RNA probe was added, and the membranes were incubated for $1 \mathrm{hr}$ at room temperature with continuous shaking. The membranes were washed three times for $10 \mathrm{~min}$ each in probe buffer and exposed to X-ray film at $-70 \mathrm{C}$ with a intensifying screen. The ${ }^{32} \mathrm{P}$-labeled probe was prepared by labeling the $5^{\prime}$ terminus of virion RNA as follows: Viral genomic RNA was dissolved in $50 \mathrm{mM}$ Tris- $\mathrm{HCl}, \mathrm{pH} 8.5$, and incubated at $90 \mathrm{C}$ for $30 \mathrm{~min}$. The RNA was added to a $50 \mu \mathrm{l}$ reaction containing $50 \mathrm{mM}$ Tris- $\mathrm{HCl}, \mathrm{pH} 7.6,10 \mathrm{mM} \mathrm{MgCl} 2,10 \mathrm{mM}$ ß-mercaptoethanol, $100 \mu \mathrm{Ci}$ [gamma- ${ }^{32} \mathrm{P}$ ] ATP (New England Nuclear, 3,000 Ci/mmol), and 5 units of T4 polynucleotide kinase (United States Biomedical, Amersham Canada Ltd.). The reaction was incubated for $30 \mathrm{~min}$ at $37 \mathrm{C}$ 


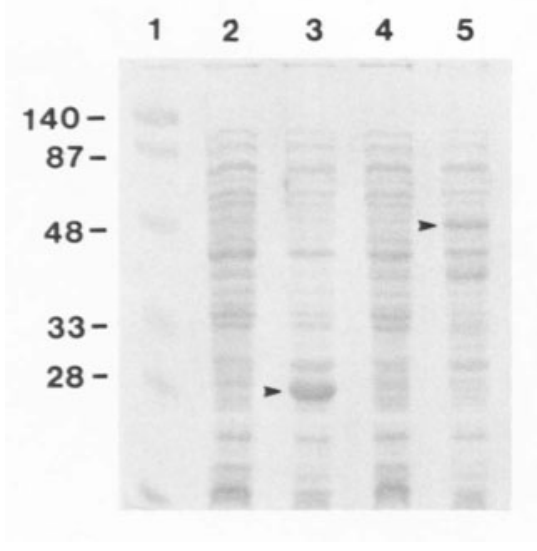

Figure 1. Expression of the GST-fusion protein in E. coli. The transformants were grown in $2 \mathrm{X}$ YT broth containing $2 \%$ glucose until OD reached 0.5 at $600 \mathrm{~nm}$. IPTG was added to a final concentration of $2 \mathrm{mM}$, and the cultures were incubated for 2 additional hours. Cells were lysed in sample buffer, and the total proteins were resolved by $12 \%$ SDS-PAGE followed by Coommassie blue staining. Each lane represents approximately $150 \mu \mathrm{l}$ of the culture. Lanes: 1 , molecular weight marker; 2, uninduced GST alone; 3, IPTG-induced GST alone; 4, uninduced GST-fusion protein; 5, IPTG-induced GST-fusion protein. Arrow heads indicate the expressed proteins.

and terminated by addition of EDTA. The end-labeled RNA was separated from unincorporated radionucleotides by Sephadex G-50 column chromatography and ethanol precipitation.

\section{RESULTS}

A 759 base pair DNA fragment was PCR-cloned representing the region of nucleotide positions 4919-5677 upstream from the $32 \mathrm{~K}$ non-structural protein gene ${ }^{6}$ of bovine coronavirus. The cloned DNA fragment was inserted in-frame behind the glutathione S-transferase (GST) gene for expression as a fusion protein. High level expression of the GST-fusion protein was achieved under the control of a tac promoter using IPTG induction. Total cell lysates were prepared for SDS-PAGE, and the expressed proteins were visualized by Coommassie blue staining (Fig 1). Polypeptides with approximate molecular weights of 28 $\mathrm{kDa}$ and $55 \mathrm{kDa}$ were identified in the IPTG-induced cultures (Fig. 1, lanes 3, 5). These proteins were not present in uninduced cultures (lanes 2, 4), and the specificity of these proteins were confirmed by immunoblotting with anti-GST antibody.

The cysteine/histidine residues present in the ORF1b region of coronavirus are similar to the configuration found in zinc-binding proteins ${ }^{5}$. To examine if this domain in coronavirus represents zinc-finger, a solid-phase zinc blot assay was performed. Proteins were resolved by SDS-PAGE and immobilized on the membrane under reducing conditions. The membrane was incubated with $\mathrm{Zn}^{65}$ and exposed to X-ray film. The fusion protein containing the cysteine/histidine rich domain bound to $\mathrm{Zn}^{65}$ (Fig. 2, lane 4), and this reaction was specific since none of the other bacterial proteins nor GST alone bound to $\mathrm{Zn}^{65}$ (Fig. 2, lanes 1, 2, 3).

Zinc-finger motifs are often found in RNA binding proteins. To examine if the coronavirus motif was able to bind to the viral RNA, protein-RNA hybridization was carried out. This technique has been used for protein-RNA interaction studies for reovirus and coronavirus $^{1,12}$. Protein-bound membrane was probed with coronavirus genomic RNA labeled with ${ }^{32} \mathrm{P}$. Binding of the fusion protein to coronavirus genomic RNA was not detected (Fig. 3, lane 3), whereas the BCV nucleocapsid protein efficiently bound to the viral RNA (Fig., 3, lane 1). Since the Northwestern protocol involves protein denaturation steps, we employed a filter binding assay to re-examine the RNA binding activity of the zinc protein ${ }^{9}$. The cell lysates were incubated with the radiolabeled genomic RNA in binding buffer, and the mixture was filtered through a nitrocellulose membrane. The membrane was washed with the binding buffer and counted for radioactivity. Approximately $80 \%$ of the input radioactivity was incorporated with the GST-fusion protein, whereas the GST alone remained only $40 \%$ (Fig. 4). 
A

QSGFKKLVSPSSAVEKCIVSVSYRGNNLNG

LWLGDTIYCPRHELGKFSGDQWNDVLNLAN

NHEFEVTTQHGVTLNVVSRRLKGAVLILQT

$\mathrm{X} 16.3 \mathrm{E} \longrightarrow \mathrm{N}$
$\mathrm{X} 16.13 \mathrm{E} \longrightarrow \mathrm{D}$
AVANAETPKYKFIKANCGDSFTIACAYGGT

VVGLYPVTMRSNGTIRASFLAGACGS-QS

$\mathrm{X} 17 \mathrm{C} \longrightarrow \mathrm{A}$

--QS---QG---QG----QS----QS

3928
--QS- 100 kDa protein-Q

$\mathrm{X} 20 \mathrm{~S} \rightarrow \mathrm{A}$

Figure 2. Zinc-binding activity of the fusion protein. Total proteins were resolved by SDS-PAGE and immobilized on PVDF membrane. The membrane was incubated in labeling buffer containing $1 \mu \mathrm{Ci} / \mathrm{ml}$ of $\mathrm{Zn}^{65}$ for $1 \mathrm{hr}$. The membrane was washed twice with the labeling buffer and exposed to X-ray film. Lanes: 1, uninduced GST alone; 2, IPTG-induced GST alone; 3, uninduced GST-fusion protein; 4, IPTG-induced GST-fusion protein.

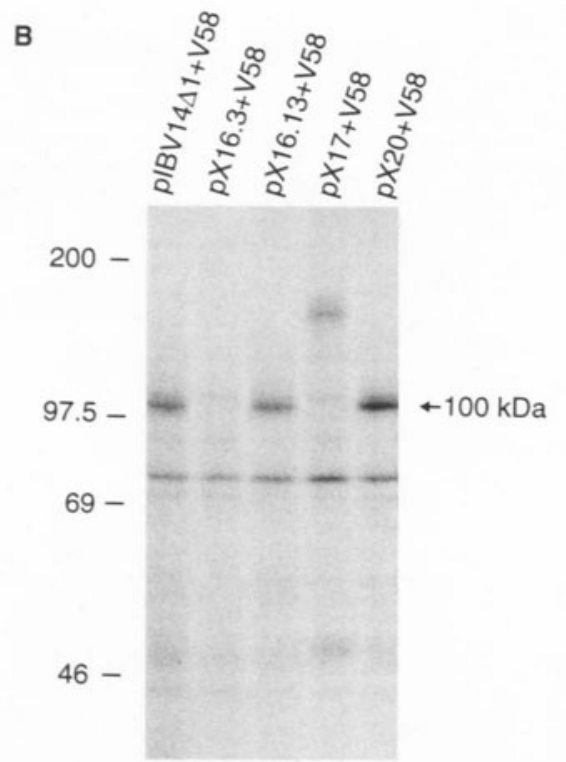

Figure 3. Northwestern blot hybridization of the fusion protein. Total cell lysates were resolved by SDS-PAGE and immobilized on PVDF membrane. Coronavirus genomic RNA was extracted from the sucrose-purified virions, and the RNA was in vitro-labeled with [gamma- ${ }^{32} \mathrm{P}$ ] using a polynucleotide kinase. The membrane was hybridized with the ${ }^{32} \mathrm{P}$-labeled RNA probe, and exposed to X-ray film. Lanes: 1, purified coronavirus; 2, IPTG-induced GST alone; 3, IPTG-induced GST-fusion protein.

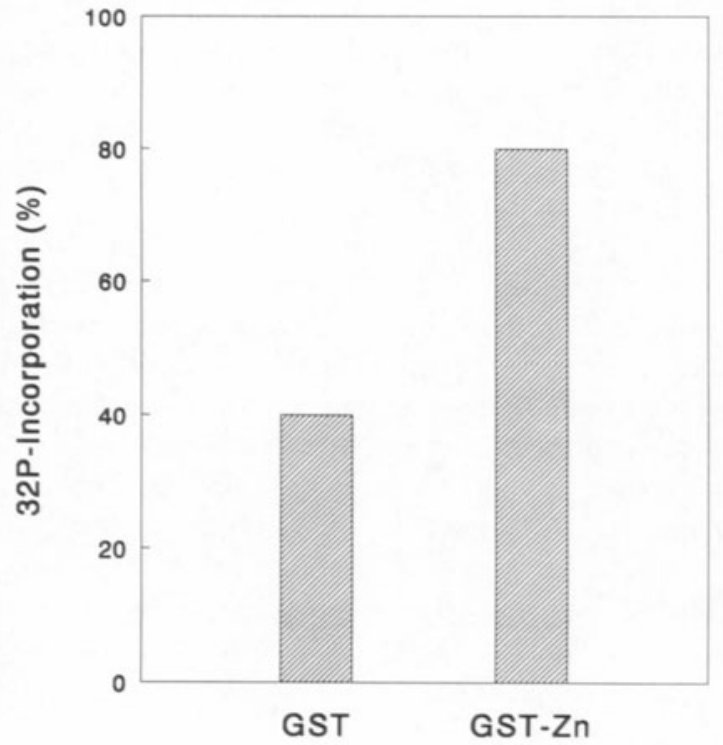

Figure 4. RNA-binding of the GST-fusion protein. The cell lysate was incubated with ${ }^{32} \mathrm{P}$-labeled BCV RNA in $50 \mu \mathrm{l}$ of binding buffer (17 mM HEPES-KOH, pH 7.2, $2 \mathrm{mM}$ DTT, $5 \%$ glycerol, $0.5 \mathrm{mM}$ magnesium acetate, $75 \mathrm{mM} \mathrm{KCl}$ ), containing $100 \mu \mathrm{g} / \mathrm{ml}$ of bovine resum albumin. The mixture was filtered through a nitrocellulose membrane, and the filter was washed with binding buffer, airdried, and counted in a scintillation counter. Input radioactivity was 20,000 counts per minute. 


\section{DISCUSSION}

We cloned and expressed the sequence representıng the cysteıne-rich region of bovine coronavirus ORF1b in $E$ coll This region represents nucleotide positions 4919-5677 upstream from the initiation codon of the $32 \mathrm{~K}$ non-structural protein gene The structural arrangements in the cysteine-rich domain was highly conserved among coronaviruses, and the cysteine/histidine cluster resembles a zinc-finger motıf which is commonly represented as several repeats of Cys-X-X-Cys/His, where X is any amıno acid Using the GST-fusion protein expressed in $E$ coll, we demonstrated that the polypeptide representing the cysteine-rich region was a zinc-binding protein The zinc-finger motif is often found in eukaryotic regulartory proteins and is able to bind to $\mathrm{zinc}^{5}$ Cysteines and histidines form ligands co-ordınatıng zınc atoms, promotıng sequence specific protein-DNA interactions Zinc ion is either involved in maintaining an intramolecular conformation or mediates an intermolecular linkage between two molecules resultıng in the dimerization The most catalytic function of DNA-binding protein occurs in the cell nucleus However, since coronavirus replication takes place in the cytoplasm and the coronavirus zinc-finger motif is found in the putatıve RNA polymerase region, we speculate that the coronavirus zinc-finger may be involved in the binding of the RNA polymerase molecule to the viral RNAs, and thereby facilitates initiation of viral replication and transcription By Northwestern blot hybridization, we were not able to detect binding of the fusion protein to coronavirus RNA, while the BCV nucleocapsid protein used as control bound to the viral RNA This was probably due to the fact that the Northwestern hybridization protocol involved a protein denaturation step which altered the protein conformation neccessary for the interaction with RNA By the native filter-binding assay, we demonstrated that the fusion protein bound to the the coronavirus genomic RNA Studies to further elucidate the RNA-protein interaction and function of the zinc protein in coronavirus replication are in progress

\section{ACKNOWLEDGMENTS}

This study was supported by grants from Health Services Utılization and Research Commision of Saskatchewan, Natural Sciences and Engineering Research Council of Canada, and Medical Research Council of Canada Published as a journal series No 178 with the permission of the director of VIDO

\section{REFERENCES}

1 Boyle, L F, Holmes, K V RNA-bınding proteins of bovine rotavirus $1986 \mathrm{~J}$ Virol $58561-568$

2 Boursnell, M E G, Brown, T D K, Foulds, I J, Green, P F, Tomley, F M, and Bınns, M M Completion of the sequence of the genome of the coronavirus avian infectious bronchitis virus $1987 \mathrm{~J}$ Gen Virol 68 57-77

3 Bredenbeek, P J, Pachuk, C J, Noten, A F, Charıte, J, Luytjes, W, Weiss, S R, Spaan, W J 1990 The primary structure and expression of the second open reading frame of the polymerase gene of the coronavirus MHV-A59 A highly conserved polymerase is expressed by an efficient frameshiftıng mechanısm Nucl Acids Res 18 1825-1832

4 Brierley, I, Digard, P, Inglis, S C Characterization of an efficient coronavirus ribosomal frameshiftıng signal requirment for an RNA pseudoknot 1989 Cell 57 537-547

5 Coleman, J E Zınc proteins enzymes, storage proteins, transcription factors, and replication proteins Annu Rev Biochem 61 897-946

6 Cox, G J , Parker, M D , Babıuk, L A The sequence of cDNA of bovine coronavirus 32K nonstructural gene 1989 Nucl Acids Res 175847 
7 Herold, J, Raabe, T, Schelle-Prınze, B, Siddel, S G Nucleotide sequence of the human coronavirus 229E RNA polymerase locus Virology 195 680-691

8 Lee, H J, Shieh, C K, Gorbalenya, A E, Koonın, E V, Monıca, N L , Tuler, J, Bagdzhadzhyan, A, La1, M M C The complete sequence ( 22 kilobases) of murine coronavirus gene 1 encoding the putative protease and RNA polymerase 1991 Virology $180567-582$

9 Pachuk, C J, Bredenbeek, P J, Zoltık, P W, Spaan, W J M, Weiss, S Molecular clonıng of the gene encodıng the putatıve polymerase of mouse hepatıtıs coronavırus, strain A59 1989 Virology 171 $141-148$

10 Robbıns, S G , Frana, M F, McGowan, J J , Boyle, J F, Holmes, K V RNA-binding proteins of MHV detection of monomeric and multımeric $N$ protein with an RNA overlay-protein blot assay 1986 Virology $150 \quad 402-410$

11 Schiff, L A, Nibert, M L, Field, B N Characterization of a zinc blottıng technique evidence that a retroviral gag protein binds zinc 1988 Proc Natl Acad Scı USA 85 4195-4199

12 Methot, N, Pause, A, Hershey, J W B, Sonenberg, N The translation initiation factor eIF-4B contains an RNA-binding region that is distınct and independent from its ribonucleoprotein consensus sequence 1994 Mol Cell Biol 14 2307-2316 